\title{
Comparative Toxicity of Bacillus thuringiensis var. israelensis Crystal Proteins in vivo and in vitro
}

\author{
By CHRIS N. CHILCOTT*† AND DAVID J. ELLAR \\ Department of Biochemistry, University of Cambridge, Tennis Court Road, \\ Cambridge CB2 $1 Q W, U K$
}

(Received 19 January 1988; revised 9 May 1988)

\begin{abstract}
Bacillus thuringiensis var. israelensis crystal proteins were purified by FPLC on a Mono Q column to yield $130,65,28,53,30-35$ and $25 \mathrm{kDa}$ proteins. All the purified proteins killed Aedes aegypti larvae after citrate precipitation, but the $65 \mathrm{kDa}$ protein was the most toxic. A precipitated mixture of 27 and $130 \mathrm{kDa}$ proteins was almost as toxic as solubilized crystals. In assays against a range of insect cell lines, the activated form $(25 \mathrm{kDa})$ of the $27 \mathrm{kDa}$ protein was generally cytotoxic with the lowest $\mathrm{LC}_{50}$ values in vitro. By contrast, the activated forms of the $130 \mathrm{kDa}$ and $65 \mathrm{kDa}$ protoxins ( $53 \mathrm{kDa}$ and $30-35 \mathrm{kDa}$ proteins, respectively) were much more specific than the $25 \mathrm{kDa}$ protein in their action on dipteran cells, and each showed a unique toxicity profile which, in the case of the $130 \mathrm{kDa}$ preparation, was restricted to Anopheles and Culex cell lines.
\end{abstract}

\section{INTRODUCTION}

Bacillus thuringiensis var. israelensis (Bti), during sporulation, produces a protein crystal that is toxic to mosquito and blackfly larvae (Goldberg \& Margalit, 1977). The Bti crystal contains three major proteins of $27 \mathrm{kDa}, 65 \mathrm{kDa}$ and a doublet of $130 \mathrm{kDa}$, but the role of each of these in determining the insecticidal specificity and potency of the crystal is not known. The toxicity of native crystals against mosquito larvae ranges from $0.2-5 \mathrm{ng} \mathrm{ml}^{-1}$ (Thomas \& Ellar, 1983; Yamamoto et al., 1983). Because mosquito larvae are filter feeders, the soluble proteins have been attached to latex beads (Schnell et al., 1984), encapsulated (Cheung \& Hammock, 1985) or precipitated (Insell \& Fitz-James, 1985) to increase the amount of the protein ingested by the larvae. Reported $\mathrm{LC}_{50}$ values for the purified components are $40 \mathrm{ng} \mathrm{ml}^{-1}$ for the $130 \mathrm{kDa}$ doublet (Visser et al., 1986), 43-600 $\mathrm{ng} \mathrm{ml}^{-1}$ for the $65 \mathrm{kDa}$ protein (Insell \& Fitz-James, 1985; Ibarra \& Federici, 1986) and 125-1000 $\mathrm{ng} \mathrm{m}^{-1}$ (Visser et al., 1986; Ward et al., 1986) for the $27 \mathrm{kDa}$ protein. Wu \& Chang (1985) reported that when 27 plus $65 \mathrm{kDa}$ or 27 plus $130 \mathrm{kDa}$ proteins were fed to mosquito larvae, the toxicity of each mixture was greater than if each protein had been fed alone, suggesting that they acted synergistically. The $25 \mathrm{kDa}$ protein derived from proteolysis of the $27 \mathrm{kDa}$ protein is cytolytic (Thomas \& Ellar, 1983; Armstrong $e t$ al., 1985), haemolytic, neurotoxic (Chilcott et al., 1984; Singh \& Gill, 1985) and toxic to suckling mice (Thomas \& Ellar, 1983).

Here, we report the isolation of the crystal proteins $(130,65$ and $28 \mathrm{kDa}$ proteins) and their proteolytic products $(53,30-35$ and $25 \mathrm{kDa}$ proteins), comparing their toxicity, alone and in combination, to mosquito larvae and to insect cell lines.

\footnotetext{
† Present address: Entomology Division, DSIR, Private Bag, Auckland, New Zealand.

Abbreviations: $\mathrm{LC}_{50}$, concentration of toxin required to kill $50 \%$ of the mosquito larvae or tissue culture cells; FPLC, fast protein liquid chromatography.
} 


\section{METHODS}

Purification of Bti crystals. Bacillus thuringiensis var. israelensis (IPS78) was obtained from H. de Barjac (Institut Pasteur, Paris, France). Bacteria were grown in 31 of casein yeast medium (Stewart et al., 1981) at $30^{\circ} \mathrm{C}$ for 24 $36 \mathrm{~h}$ on an orbital shaker (200 r.p.m.). The sporulated culture was harvested by centrifugation $(12000 \mathrm{~g}, 15 \mathrm{~min})$ and the pellet was washed six times with distilled water. The crystals were purified by ultracentrifugation on discontinuous sucrose gradients as described by Thomas \& Ellar (1983).

Protein estimation. The protein concentration was determined by the method of Petersen (1977) using bovine serum albumin (Sigma) as a standard.

$S D S-P A G E$. Separation of the proteins on 10 or $13 \%$ SDS-polyacrylamide gels was done as described by Thomas \& Ellar (1983).

Insect cell lines. Aedes albopictus cells (Diptera, trypsinized larval tissue, obtained from Mrs T. Lescott, NERC, Institute of Virology, Oxford, UK), Aedes aegypti cells (Diptera, trypsinized larval tissue) and Culex quinquefascatus cells (Diptera, larval tissue, obtained from Dr D. W. Roberts, Boyce Thompson Institute, Ithaca, USA), were grown in Mitsuhashi and Maramorosch medium (Hink, 1972). Drosophila melanogaster cells (Diptera, ovarian tissue, obtained from Mrs T. Lescott), were grown in Schneider's Drosophila medium (Hink, 1972). Anopheles gambiae and Anopheles stephensi (Diptera, trypsinized larval tissue, obtained from Dr Varma, School of Hygiene and Tropical Medicine, London, UK) were grown in MK/VP12 medium (Hink, 1972).

Choristoneura fumiferana CF1 and 63CF1 cells (Lepidoptera, spruce budworm, trypsinized larval tissue, obtained from Dr S. S. Sohi, Canadian Forest Pest Management Institute, Ontario, Canada) and C. fumiferana H11 cells (obtained from Dr D. Edwards, Mycogen Corporation, San Diego, USA) were grown in Grace's medium (Hink, 1972). Spodoptera frugiperda (Lepidoptera, fall armyworm, pupal ovary), Heliothis zea (Lepidoptera, cotton bollworm, adult ovary), Trichoplusia ni (Lepidoptera, cabbage looper, adult ovary) and Mamestra brassicae cells (Lepidoptera, cabbage moth) were obtained from Mrs T. Lescott and grown in TC100 medium (Gardiner \& Stockdale, 1975). Lymantria dispar cells (Lepidoptera, adult ovary) were obtained from Biological Sciences Research Centre, Shell Development Company, and grown in TC100 medium. All media contained 10\%(v/v) foetal calf serum (Gibco) and gentamycin $\left(50 \mu \mathrm{g} \mathrm{ml}^{-1}\right)$. Cells were grown at $28{ }^{\circ} \mathrm{C}$.

Purification of the crystal proteins. To isolate the crystal proteins several methods were used.

(a) 27 and $130 \mathrm{kDa}$ proteins. Purified crystals were incubated in $50 \mathrm{~mm}-\mathrm{Na}_{2} \mathrm{CO}_{3} / \mathrm{HCl}, \mathrm{pH} 10 \cdot 3$, at $37^{\circ} \mathrm{C}$ for $60 \mathrm{~min}$, followed by centrifugation at $10000 \mathrm{~g}$ for $10 \mathrm{~min}$ in an Eppendorf Minifuge. The pellet was incubated at $50 \mathrm{mM}-\mathrm{Na}_{2} \mathrm{CO}_{3} / \mathrm{HCl}, \mathrm{pH} 9 \cdot 5$, containing $5 \mathrm{~mm}$-phenylmethylsulphonyl fluoride and $10 \mathrm{mM}-\mathrm{EDTA}$ at $37^{\circ} \mathrm{C}$ for $45 \mathrm{~min}$. Dithiothreitol was added to a final concentration of $10 \mathrm{mM}$, and the sample incubated at $37^{\circ} \mathrm{C}$ for a further $30 \mathrm{~min}$. Purification of the 27 and $130 \mathrm{kDa}$ proteins from this solution was done using fast protein liquid chromatography (FPLC) on a Mono Q column (Pharmacia). The column was equilibrated with $10 \mathrm{mM}$ $\mathrm{NH}_{4} \mathrm{HCO}_{3}, \mathrm{pH} 8.5$ (pH adjusted with ammonia solution), and the protein was eluted using a $10-800 \mathrm{mM}-$ $\mathrm{NH}_{4} \mathrm{HCO}_{3}$ (pH 8.5) gradient, over $40 \mathrm{~min}$, at a flow rate of $1 \mathrm{ml} \mathrm{min}{ }^{-1}$.

(b) $25 \mathrm{kDa}$ protein. Fractions containing the $27 \mathrm{kDa}$ protein peak from the FPLC were pooled and incubated with trypsin $\left(20 \mu \mathrm{g} \mathrm{ml}^{-1}\right)$ at $37^{\circ} \mathrm{C}$ for $30 \mathrm{~min}$. The sample $(3 \mathrm{ml})$ was applied to the Mono $\mathrm{Q}$ column and eluted using a $10-600 \mathrm{mM}^{-\mathrm{NH}_{4}} \mathrm{HCO}_{3}(\mathrm{pH} \mathrm{8.5)}$ gradient.

(c) $53 \mathrm{kDa}$ protein. The fractions containing the $130 \mathrm{kDa}$ protein peak were incubated with trypsin $\left(100 \mu \mathrm{g} \mathrm{ml}^{-1}\right)$ at $37^{\circ} \mathrm{C}$ for $2 \mathrm{~h}$. The sample was applied to the Mono $\mathrm{Q}$ column equilibrated with $10 \mathrm{~mm}$ $\mathrm{NH}_{4} \mathrm{HCO}_{3}, \mathrm{pH} \mathrm{10}$, and eluted (with a stepwise gradient) at $472 \mathrm{mM}-\mathrm{NH}_{4} \mathrm{HCO}_{3}, \mathrm{pH} 10$.

(d) $65 \mathrm{kDa}$ protein. Bti crystals were incubated in $50 \mathrm{mM}-\mathrm{Na}_{2} \mathrm{CO}_{3} / \mathrm{HCl}, \mathrm{pH} 9.5$, containing $10 \mathrm{mM}-$ dithiothreitol, at $37^{\circ} \mathrm{C}$ for $60 \mathrm{~min}$. The sample was centrifuged and the pellet incubated in $50 \mathrm{mM}-\mathrm{Na}_{2} \mathrm{CO}_{3}$, $\mathrm{pH} 11 \cdot 3$, at $37^{\circ} \mathrm{C}$ for $60 \mathrm{~min}$. The $65 \mathrm{kDa}$ protein was purified on a Sephadex G-75 column equilibrated with $50 \mathrm{~mm}-\mathrm{NH}_{4} \mathrm{HCO}_{3}, \mathrm{pH} 8 \cdot 5$, and eluted at a flow rate of $12 \mathrm{ml} \mathrm{h}^{-1}$.

(e) $30-35 \mathrm{kDa}$ proteins. Fractions under the $65 \mathrm{kDa}$ protein peak were pooled and incubated with trypsin $\left(20 \mu \mathrm{g} \mathrm{ml}^{-1}\right)$ at $37^{\circ} \mathrm{C}$ for $30 \mathrm{~min}$. The $30-35 \mathrm{kDa}$ proteins were eluted (with a stepwise gradient) at $407 \mathrm{mM}$ $\mathrm{NH}_{4} \mathrm{HCO}_{3}, \mathrm{pH} 10$.

Mosquito bioassay. Mosquito bioassays were done using 5-d-old Aedes aegypti larvae grown from eggs, generously supplied by Mr D. Funnel (Shell Research). The purified proteins were precipitated by adjusting the $\mathrm{pH}$ of the sample to $\mathrm{pH} 4.5$ with $12 \%(\mathrm{w} / \mathrm{v})$ citric acid, and kept at $-20^{\circ} \mathrm{C}$ for $3 \mathrm{~h}$. The precipitate was centrifuged at $15000 \mathrm{~g}$ for $15 \mathrm{~min}$ and washed with $2 \mathrm{mM}$-sodium citrate buffer, $\mathrm{pH} 4.5$. Toxicity of solubilized Bti crystals was determined after the following treatment. The crystals were incubated in $50 \mathrm{mM}-\mathrm{Na}_{2} \mathrm{CO}_{3} / \mathrm{HCl}, \mathrm{pH} 9 \cdot 5$, containing $10 \mathrm{~mm}$-dithiothreitol at $37^{\circ} \mathrm{C}$ for $60 \mathrm{~min}$ and centrifuged. The supernatant was collected and the pellet incubated in $50 \mathrm{~mm}-\mathrm{Na}_{2} \mathrm{CO}_{3}, \mathrm{pH} 11.3$, at $37^{\circ} \mathrm{C}$ for $60 \mathrm{~min}$. Both supernatants were pooled and precipitated as above. All bioassays were done in $2 \mathrm{mM}$-sodium citrate buffer, $\mathrm{pH} 4.5$, to prevent solubilization of the precipitated protein, with appropriate controls. Mortality was recorded at $24 \mathrm{~h}$ and the $\mathrm{LC}_{50}$ values calculated using interpolation.

Tissue culture assay. Insect cells were harvested and resuspended at $5 \times 10^{5}$ cells $\mathrm{ml}^{-1}$. Samples $(100 \mu \mathrm{l})$ of the cell suspension were added to each well of a 96 well microtitre plate. The plates were pretreated with collagen (rat 
tail, Sigma) at $1 \mathrm{mg} \mathrm{ml}^{-1}$ or with $1 \%(\mathrm{w} / \mathrm{v})$ gelatin for the lepidopteran cells. All cells were incubated at $28^{\circ} \mathrm{C}$ for $2 \mathrm{~h}$. The tissue culture medium was removed and $100 \mu \mathrm{l}$ of the toxin, diluted in tissue culture medium, was added. Cells were incubated at $28^{\circ} \mathrm{C}$ for $30 \mathrm{~min}(27,25,65$ and $30-35 \mathrm{kDa}$ proteins) or $90 \mathrm{~min}(130$ and $53 \mathrm{kDa}$ proteins). Cells were then washed twice with Dulbecco's phosphate-buffered saline (Oxoid) (PBS). Neutral red (100 $\mu 1$, $0.5 \mathrm{mg} \mathrm{ml}^{-1}$ ) solution was added to each well and the trays were incubated at $28^{\circ} \mathrm{C}$ for $90 \mathrm{~min}$. The cells were washed twice with PBS and $200 \mu$ of acid-ethanol solution [equal volume of Sørensen citrate buffer (Perin \& Dempsey, 1974), pH 4.2, and ethanol] was added to each well. Absorbance in each well was determined with an ELISA reader (Dynatech) at $540 \mathrm{~nm}$.

\section{RESULTS}

The crystal proteins were purified by selective solubilization and ion-exchange chromatography (Fig. 1). FPLC of soluble Bti proteins on a Mono Q column at $\mathrm{pH} 8.5$ resulted in the purification of the 27 and $130 \mathrm{kDa}$ proteins (Fig. 2), and the $25 \mathrm{kDa}$ protein following tryptic digestion of the $27 \mathrm{kDa}$ protein (Fig. 3). The $65 \mathrm{kDa}$ protein was purified by gel filtration on Sephadex G-75 column (Fig. 4). Following tryptic digestion of the 130 and $65 \mathrm{kDa}$ proteins, the $53 \mathrm{kDa}$ (Fig. 5) and 30-35 kDa proteins (Fig. 6) were purified on a Mono $\mathrm{Q}$ column equilibrated with $\mathrm{NH}_{4} \mathrm{HCO}_{3}, \mathrm{pH} 10$.

The toxicity of the purified proteins against Aedes aegypti larvae is shown in Table 1. Mixtures of the 130,65 and $27 \mathrm{kDa}$ proteins were tested against the mosquito larvae to investigate a possible synergistic relationship between the proteins (Table 2). The ratios of the proteins tested were similar to those observed in the native crystals. A mixture of 130 and $27 \mathrm{kDa}$ proteins $(0.25: 1, \mathrm{w} / \mathrm{w})$ had an $\mathrm{LC}_{50}$ value of $7.5 \mathrm{ng} \mathrm{ml}^{-1}$, which was more toxic than if either alone had been fed to the larvae $\left(\mathrm{LC}_{50}\right.$ of $27 \mathrm{kDa}$ is $115 \mathrm{ng} \mathrm{ml}^{-1}$; $\mathrm{LC}_{50}$ of $130 \mathrm{kDa}$ is $32 \mathrm{ng} \mathrm{ml}^{-1}$ ).

The toxicities of the purified proteins to five dipteran and seven lepidopteran cell lines were compared using the neutral red tissue culture assay (Table 3 ). Complete loss of viability occurred in 20-30 min when Aedes aegypti cells were incubated with $25 \mathrm{kDa}$ protein $\left(8 \mu \mathrm{g} \mathrm{ml}^{-1}\right)$ (Fig. 7$)$ or when Anopheles gambiae cells were incubated with $30-35 \mathrm{kDa}$ proteins $\left(200 \mu \mathrm{g} \mathrm{ml}^{-1}\right)$ (Fig. 8). However, complete loss of viability of Culex quinquefasciatus cells incubated with $53 \mathrm{kDa}$ protein $\left(150 \mu \mathrm{g} \mathrm{ml}^{-1}\right)$ took $90 \mathrm{~min}$ to occur (Fig. 9).

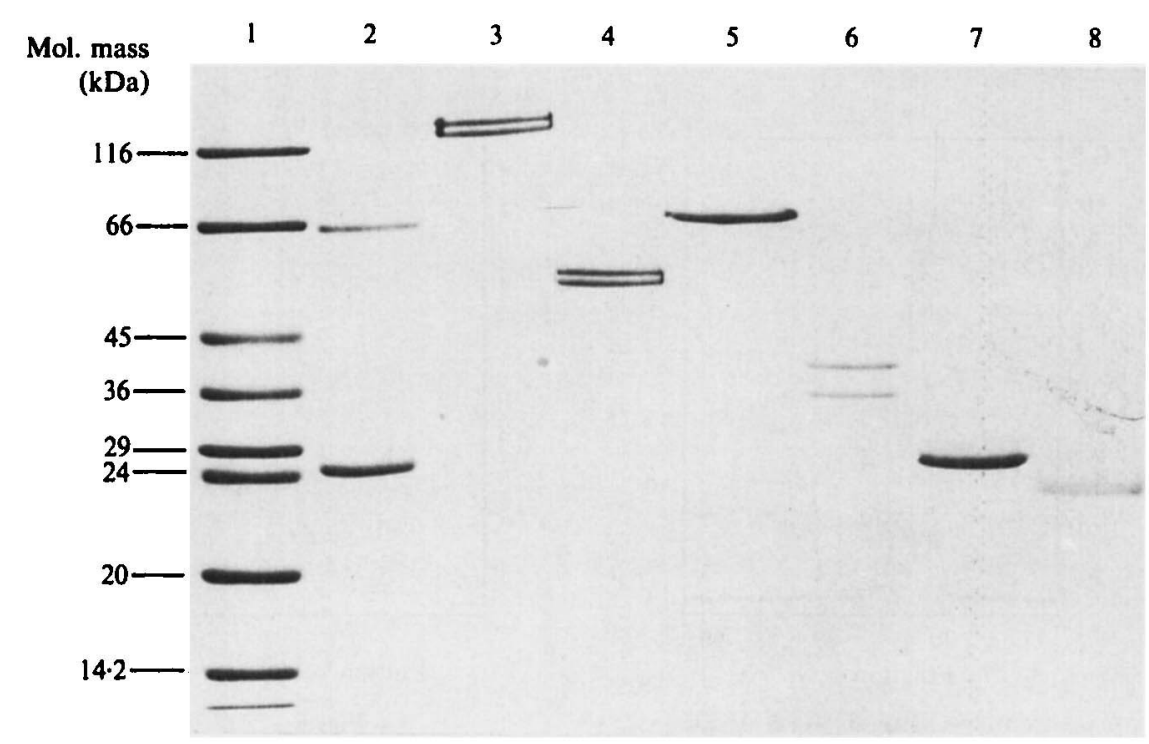

Fig. 1. SDS-PAGE of Bti crystal proteins. Lane 1, molecular mass standards; lane 2, $100 \mu \mathrm{g}$ native $B t i$ crystals; lane $3,50 \mu \mathrm{g} 130 \mathrm{kDa}$ doublet; lane 4,50 $\mathrm{g} 53 \mathrm{kDa}$ protein; lane $5,50 \mu \mathrm{g} 65 \mathrm{kDa}$ protein; lane $6,40 \mu \mathrm{g} 30-35 \mathrm{kDa}$ proteins; lane $7,30 \mu \mathrm{g} 27 \mathrm{kDa}$ protein; lane $8,25 \mathrm{kDa}$ protein. 


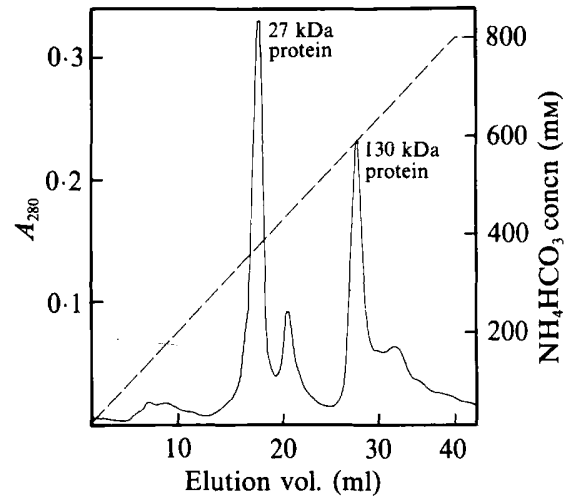

Fig. 2

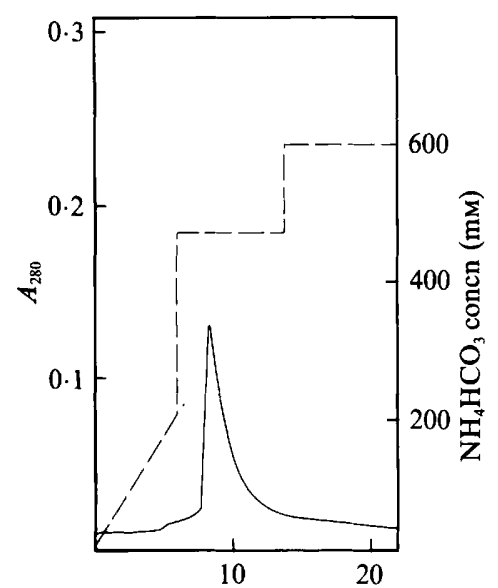

Elution vol. (ml)

Fig. 4

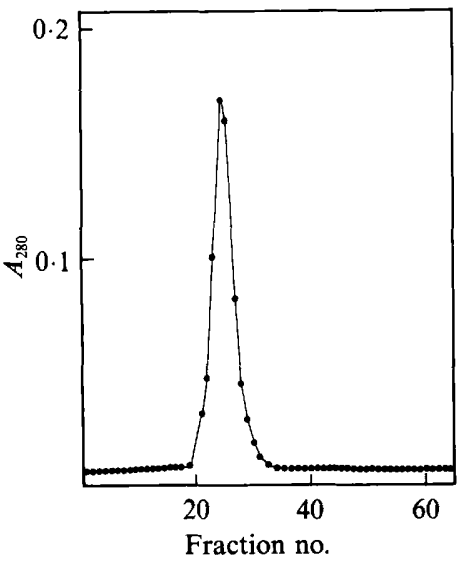

Fig. 5

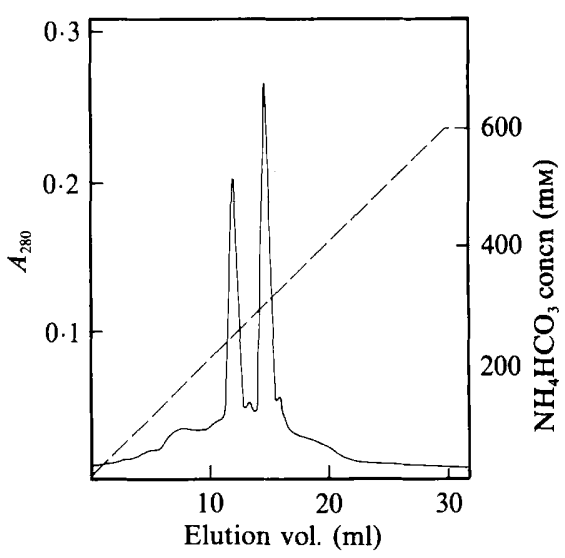

Fig. 3

Fig. 2. Purification of the 27 and $130 \mathrm{kDa}$ proteins by FPLC using a Mono $\mathrm{Q}$ column, equilibrated with $10 \mathrm{mM}-\mathrm{NH}_{4} \mathrm{HCO}_{3}$, pH 8.5 (elution gradient $10-800 \mathrm{~mm}-\mathrm{NH}_{4} \mathrm{HCO}_{3}$; flow rate 1 $\left.\mathrm{ml} \mathrm{min}{ }^{-1}, 40 \mathrm{~min}\right) .-, A_{280} ;---, \mathrm{NH}_{4} \mathrm{HCO}_{3}$ concn.

Fig. 3. Purification of the $25 \mathrm{kDa}$ protein by FPLC using a Mono Q column (elution gradient of $10-600 \mathrm{mM}-\mathrm{NH}_{4} \mathrm{HCO}_{3}$, pH 8.5). - - --, As Fig 2.

Fig. 4. Purification of the $53 \mathrm{kDa}$ protein by FPLC using a Mono Q column (eluted at $472 \mathrm{mM}-\mathrm{NH}_{4} \mathrm{HCO}_{3}, \mathrm{pH} 10$ ). - , --- As Fig 2.

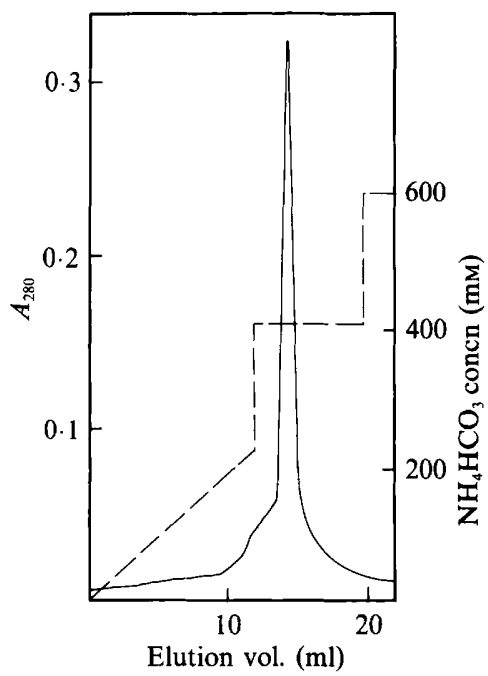

Fig. 6

Fig. 5. Gel filtration chromatography of $65 \mathrm{kDa}$ protein on a Sephadex G-75 column. Flow rate $12 \mathrm{ml}$ $\mathrm{h}^{-1}$; column size $1.6 \times 60 \mathrm{~cm}$; eluant $50 \mathrm{~mm}-\mathrm{NH}_{4} \mathrm{HCO}_{3}, \mathrm{pH} 8.5$.

Fig. 6. Purification of the $30-35 \mathrm{kDa}$ proteins by FPLC using a Mono $\mathrm{Q}$ column (eluted at $407 \mathrm{~mm}$ $\mathrm{NH}_{4} \mathrm{HCO}_{3}, \mathrm{pH}$ 10). - , - - , As Fig 2. 


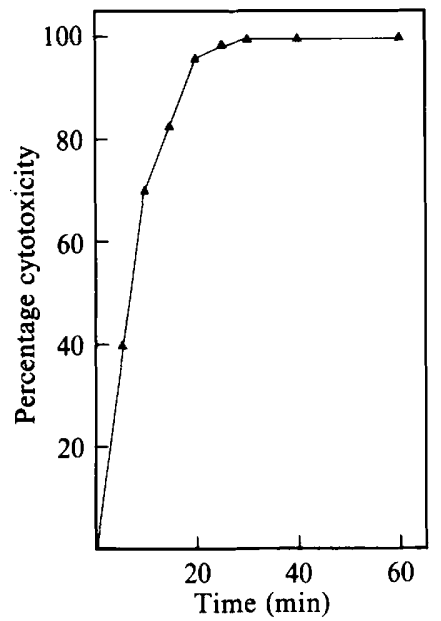

Fig. 7

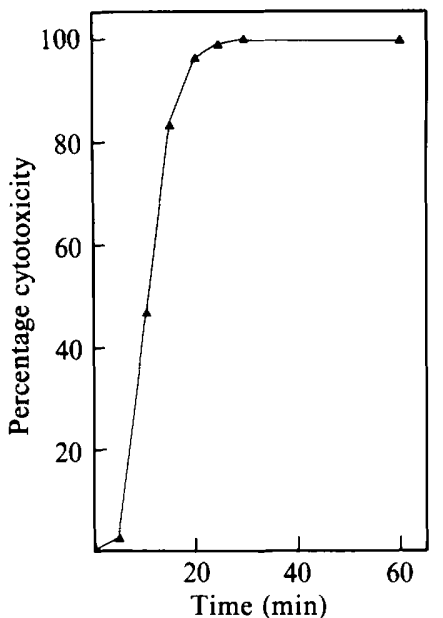

Fig. 8

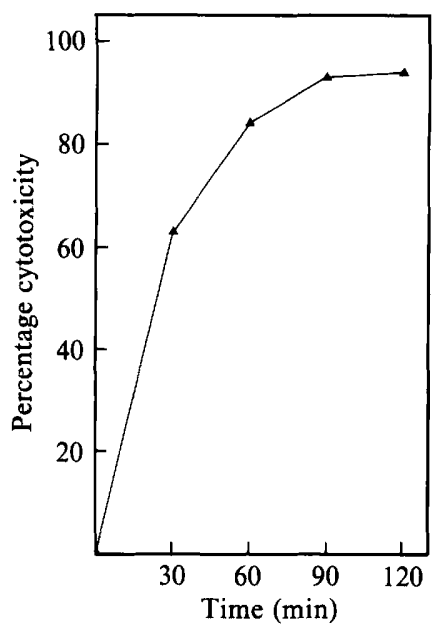

Fig. 9

Fig. 7. Time course of toxicity of Aedes aegypti cells incubated with the $25 \mathrm{kDa}$ protein $\left(8 \mu \mathrm{g} \mathrm{ml}^{-1}\right)$.

Fig. 8. Time course of toxicity of Anopheles gambiae cells incubated with the $30-35 \mathrm{kDa}$ protein $\left(200 \mu \mathrm{g} \mathrm{ml}^{-1}\right)$.

Fig. 9. Time course of toxicity of Culex quinquefasciatus cells incubated with the $53 \mathrm{kDa}$ protein $\left(150 \mu \mathrm{g} \mathrm{ml}^{-1}\right)$.

Table 1. Toxicity of Bti crystal proteins against Ae. aegypti larvae

Results are the means of four separate assays \pm SD.

$$
\text { Preparation } \quad \begin{gathered}
\mathrm{LC}_{50} \\
\text { (ng } \mathrm{ml}^{-1} \text { ) }
\end{gathered}
$$

$\begin{array}{lc}\text { Native crystals } & 0 \cdot 3 \pm 0.08 \\ \text { Solubilized crystals } & 1 \cdot 0 \pm 0 \cdot 5 \\ 130 \mathrm{kDa} \text { protein } & 32 \cdot 0 \pm 4 \cdot 0 \\ 65 \mathrm{kDa} \text { protein } & 4 \cdot 0 \pm 1 \cdot 0 \\ 27 \mathrm{kDa} \text { protein } & 115 \cdot 0 \pm 12 \cdot 5 \\ 53 \mathrm{kDa} \text { protein } & 40.0 \pm 7 \cdot 2 \\ 30-35 \mathrm{kDa} \text { protein } & 12 \cdot 0 \pm 2 \cdot 8 \\ 25 \mathrm{kDa} \text { protein } & 74.0 \pm 8 \cdot 4\end{array}$

* As described in Methods.

Table 2. Synergism in mosquitocidal activity of purified 27,65 and $130 \mathrm{kDa}$ crystal proteins from Bti Results are the means of four separate assays \pm SD.

\begin{tabular}{|c|c|}
\hline Protein combination & $\begin{array}{c}\mathrm{LC}_{50} \\
\left(\mathrm{ng} \mathrm{ml}^{-1}\right)\end{array}$ \\
\hline$(0.25: 0.75, w / w)$ & $15 \cdot 0 \pm 2 \cdot 1$ \\
\hline $\begin{array}{l}7(0 \cdot 25: 1 \cdot 0, w / w) \\
(0 \cdot 75: 1 \cdot 0, w / w) \\
5 / 27(0 \cdot 25: 0 \cdot 75: 1 \cdot 0, \text { by wt })\end{array}$ & $\begin{array}{l}7 \cdot 5 \pm 1 \cdot 8 \\
2 \cdot 0 \pm 0 \cdot 6 \\
5 \cdot 5 \pm 1 \cdot 1\end{array}$ \\
\hline
\end{tabular}

\section{DISCUSSION}

It has been reported that after solubilization the toxicity of crystal protein is reduced markedly by fifty- to one hundred-fold (Insell \& Fitz-James, 1985: Visser et al., 1986). This reduction is not due to a real loss in toxicity but rather to a reduced level of toxin ingested by the larvae because of their filter feeding behaviour. To increase the uptake of the soluble proteins we precipitated 
Table 3. Toxicity of purified Bti crystals against insect cell lines

Results are the means of four separate assays, each using a different batch of cells. In each cse the SD values were not greater than $10 \%$ of the mean. -, No toxicity at $150 \mu \mathrm{g} \mathrm{m}^{-1}(130,65,27$ and $53 \mathrm{kDa}$ proteins) or no toxicity at $100 \mu \mathrm{g} \mathrm{ml}^{-1}(30-35$ and $25 \mathrm{kDa}$ proteins).

$$
\begin{aligned}
& \mathrm{LC}_{50}\left(\mu \mathrm{g} \mathrm{ml}^{-1}\right)
\end{aligned}
$$

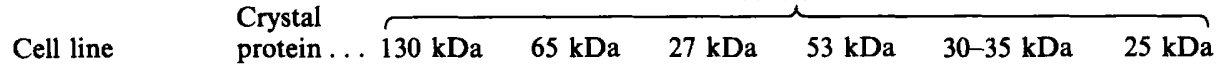

Aedes aegypti Aedes albopictus Anopheles stephensi Anopheles gambiae Culex quinquefasciatus Drosophila melanogaster Choristoneura fumiferana $\mathrm{CF} 1$

Choristoneura fumiferana 63CF1 Choristoneura fumiferana HD11

Heliothis zea

Spodoptera frugiperda

Mamestra brassicae

Lymantria dispar

$\begin{array}{llc}- & - & 25 \\ - & - & 20 \\ - & - & 9 \cdot 1 \\ - & - & 9 \cdot 5 \\ - & - & 20 \\ - & - & 7 \cdot 5 \\ - & - & 98 \\ - & - & 98 \\ - & - & 88 \\ - & - & - \\ - & - & 98 \\ 86 & - & 45 \\ - & - & 92\end{array}$

$\begin{array}{ccc}- & 125 & 2 \cdot 8 \\ - & - & 3 \\ 35 & 79 & 3 \cdot 3 \\ 23 & 78 & 2 \cdot 8 \\ 34 & 90 & 3 \\ - & 78 & 2 \cdot 6 \\ - & - & 34 \\ - & - & 31 \\ - & - & 36 \\ - & - & 68 \\ 115 & - & 11 \\ 44 & 94 & 2 \\ - & - & -\end{array}$

them at $\mathrm{pH} 4 \cdot 5$, resulting in a threefold drop in toxicity. The most toxic protein against mosquito larvae was the $65 \mathrm{kDa}$ protein, with a $\mathrm{LC}_{50}$ value of $4 \mathrm{ng} \mathrm{ml}^{-1}$. Ibarra \& Federici (1986) reported the $\mathrm{LC}_{50}$ value of the $65 \mathrm{kDa}$ protein as $43 \mathrm{ng} \mathrm{ml}^{-1}$; they also showed that proteolysis of the $65 \mathrm{kDa}$ protein with trypsin produced a $38 \mathrm{kDa}$ protein. We found that tryptic digestion of the $65 \mathrm{kDa}$ protein formed two proteins of 30 and $35 \mathrm{kDa}$. These may either come from the same $65 \mathrm{kDa}$ protein or there may be two $65 \mathrm{kDa}$ proteins in the crystal (i.e. one $65 \mathrm{kDa}$ protein forming the $30 \mathrm{kDa}$ protein and the other $65 \mathrm{kDa}$ protein forming the $35 \mathrm{kDa}$ protein). The $\mathrm{LC}_{50}$ value of $35 \mathrm{ng} \mathrm{ml}^{-1}$ for the $130 \mathrm{kDa}$ protein is similar to the value of $40 \mathrm{ng} \mathrm{ml}^{-1}$ reported by Visser et al. (1986) when the $130 \mathrm{kDa}$ protein was attached to latex beads. However, the $\mathrm{LC}_{50}$ value for the 28 and $25 \mathrm{kDa}$ proteins (attached to latex beads) reported by Visser $e t$ al. (1986) and Wu \& Chang (1985) is less than our value of $115 \mathrm{ng} \mathrm{ml}^{-1}$. Ward et al. (1986) reported that inclusions of the $27 \mathrm{kDa}$ protein produced by Bacillus subtilis cells, containing the gene coding for the $27 \mathrm{kDa}$ protein, had an $\mathrm{LC}_{50}$ value of $125 \mathrm{ng} \mathrm{ml}^{-1}$.

Wu \& Chang (1985) reported that mixtures of the 27 plus $65 \mathrm{kDa}$ proteins and also of the 27 plus $130 \mathrm{kDa}$ proteins were more toxic than if the two proteins were fed individually to the larvae, suggesting a synergistic relationship between these proteins. We observed a synergistic relationship between the 27 and $130 \mathrm{kDa}$ proteins (Table 2) but no synergism between the 27 and $65 \mathrm{kDa}$ proteins.

The use of a neutral red tissue culture assay allowed rapid comparison of the Bti crystal proteins against a range of insect cell lines. This assay is quantitative, rapid and less laborious than the trypan blue assay (Thomas \& Ellar, 1983). The $130 \mathrm{kDa}$ and $65 \mathrm{kDa}$ proteins were not toxic to any of the cell lines except for the case of the $130 \mathrm{kDa}$ protein against $M$. brassicae cells, suggesting that they are protoxins. However, the $27 \mathrm{kDa}$ protein was toxic to the insect cell lines which could suggest either the presence of contaminating $25 \mathrm{kDa}$ protein or that the $27 \mathrm{kDa}$ protein was proteolysed by enzymes in the tissue culture assay. However, silver staining of SDSpolyacrylamide gels did not indicate the presence of any $25 \mathrm{kDa}$ protein in the $27 \mathrm{kDa}$ preparations, and $27 \mathrm{kDa}$ protein incubated with culture medium in which cells had been incubated did not proteolyse the $27 \mathrm{kDa}$ protein. The $25 \mathrm{kDa}$ protein caused complete lysis of the dipteran cells in $30 \mathrm{~min}$. Thomas \& Ellar (1983) reported that Ae. albopictus cells incubated with alkali-solubilized $B t i$ crystals $\left(5 \mu \mathrm{g} \mathrm{ml}^{-1}\right)$ lysed in 30-40 min. Johnson \& Davidson (1984) reported that alkali-solubilized Bti crystals had $\mathrm{LC}_{50}$ values against Ae. aegypti and Ae. gambiae cells of $5.4 \mu \mathrm{g} \mathrm{ml}^{-1}$ and against $C$. fumiferana cells of $47.2 \mu \mathrm{g} \mathrm{ml}^{-1}$, but no toxicity against Plodia interpunctella cells. We also observed that the lepidopteran cells were tenfold less sensitive than the dipteran cells when incubated with $25 \mathrm{kDa}$ protein, and the $25 \mathrm{kDa}$ protein was not toxic to 
Lymantria dispar cells. Both the $30-35 \mathrm{kDa}$ proteins and $53 \mathrm{kDa}$ proteins were toxic mainly to the dipteran cell lines showing specificity similar to that of native crystals (i.e. toxic to mosquito larvae). When the purified proteins were assayed individually against Ae. aegypti larvae, the 65 $\mathrm{kDa}$ protein was the most toxic protein in Bti crystals, while mixtures of the 27 and $130 \mathrm{kDa}$ proteins were nearly as toxic as solubilized $B t i$ crystals.

All the purified proteins were cytotoxic after trypsin activation when assayed in vitro, but distinct differences in specificity and potency were observed. Thus the $27 \mathrm{kDa}$ protein and its 25 $\mathrm{kDa}$ product killed all cells with the exception of $L$. dispar and had the lowest $\mathrm{LC}_{50}$ values. This broad cytotoxicity is consistent with the ubiquitous phospholipid receptor for this toxin (Thomas \& Ellar, 1983). The 30-35 kDa products from the $65 \mathrm{kDa}$ protoxin killed all dipteran cells tested except Ae. albopictus and only one lepidopteran cell type. The greatest dipteran specificity in vitro was shown by the $53 \mathrm{kDa}$ products of the $130 \mathrm{kDa}$ protoxin doublet. This preparation killed all Anopheline and Culex cells but had no effect on two Aedes and one Drosophila cell line. Interestingly, it was also distinguishable from the 30-35 kDa preparation by its activity against $S$. frugiperda cells. This restricted specificity of the activated forms of the 130 and $65 \mathrm{kDa}$ protoxins compared to the $27 \mathrm{kDa}$ toxin suggests that the receptors for these two toxins are unlikely to be invariant membrane components such as phospholipids. Although we are conscious of the need to exercise caution in relating the results of such assays in vitro to crystal activity in vivo, these findings coupled with the indications of possible synergism suggest that the host range and potency in vivo of this endotoxin may be determined by individual toxins with different insect specificity acting independently and/or synergistically.

This work was supported by a grant to D. J.E from the AFRC. We thank Mrs A. Symonds for her invaluable help.

\section{REFERENCES}

Armstrong, J. L., RorhmanN, G. F. \& Beaudreau, G. S. (1985). Delta endotoxin of Bacillus thuringiensis subsp. israelensis. Journal of Bacteriology 161, 39-46.

Cheung, P. Y. K. \& Hammock, B. D. (1985). Microlipid droplet encapsulation of Bacillus thuringiensis subsp. israelensis $\delta$-endotoxin for control of mosquito larvae. Applied and Environmental Microbiology 50, 56-62.

Chilcott, C. N., Kalmakoff, J. \& Pillai, J. S. (1984). Neurotoxic and haemolytic activity of a protein isolated from Bacillus thuringiensis var. israelensis crystals. FEMS Microbiology Letters 25, 259-263.

GARDineR, G. R. \& Stockdale, H. (1975). Two tissue culture media for production of Lepidopteran and Nuclear Polyhedrosis Viruses. Journal of Invertebrate Pathology 25, 363-370.

Goldberg, L. J. \& MARgalit, J. (1977). A bacterial spore demonstrating rapid larvicidal activity against Anopheles sergentii, Uranotaenia unguiculata, Culex univitattus, Aedes aegypti and Culex pipiens. Mosquito News 37, 355-358.

HINK, W. F. (1972). In A Catalog of Invertebrate Cell Lines, vol. 2, chapter 11. Edited by C. Vago. London: Academic Press.

IBARRA, J. E. \& FEDERICI, B. A. (1986). Isolation of a relatively non-toxic 65 -kilodalton protein inclusion from the parasporal body of Bacillus thuringiensis subsp. israelensis. Journal of Bacteriology 165, 527533.

INSELL, J. P. \& FITZ-JAMES, P. C. (1985). Comparison and toxicity of the inclusion of Bacillus thuringiensis subsp. israelensis. Applied and Environmental Microbiology 5, 56-62.

JOHNSON, D. E. \& DAVIDSON, L. I. (1984). Specificity of cultured insect tissue culture cells for bioassay of entomocidal protein from Bacillus thuringiensis. In vitro 20, 66-70.

Perin, D. D. \& Dempsey, B. (1974). In Buffers for $p H$ and Metal Control, p 132. Edited by D. D. Perin. London: Chapman and Hall.

Petersen, G. L. (1977). A simplification of the protein assay of Lowry et al. which is more generally applicable. Analytical Biochemistry 83, 346-356.

Schnell, D. J., Pfannenstiel, M. A. \& Nickerson, K. W. (1984). Bioassay of solubilized Bacillus thuringiensis var. israelensis crystals by attachment to latex beads. Science 223, 1191-1193.

SinGH, G. J. P. \& Gill, S. S. (1985). Myotoxic and neurotoxic activity of Bacillus thuringiensis var. israelensis crystal toxin. Pesticide Biochemistry and Physiology 24, 406-414.

Stewart, G. S. A. B., Johnstone, K., Hogelberg, E. \& ElLAR, D. J. (1981). Commitment of bacterial spores to germinate. A measure of the trigger reaction. Biochemical Journal 196, 101-106.

Thomas, W. E. \& Ellar, D. J. (1983). Bacillus thuringiensis var. israelensis crystal $\delta$-endotoxin: effects on insect and mammalian cells in vitro and in vivo. Journal of Cell Science 60, 181-197.

Visser, B., Workum, M., Dullemans, A. \& WaAlwIJk, C. (1986). The mosquitocidal activity of Bacillus thuringiensis var. israelensis is associated with the $M_{\mathrm{r}} 230000$ and 130000 proteins. FEMS Microbiology Letters 30, 211-214.

Ward, E. S., Ridley, A. R., Ellar, D. J. \& TodD, J. A. (1986). Bacillus thuringiensis var. israelensis $\delta$ endotoxin. Cloning and expression of the toxin in sporogenic and asporogenic strains of Bacillus subtilis. Journal of Molecular Biology 191, 13-22. 
Wu, D. \& Chang, F. N. (1985). Synergism in mosquitocidal activity of 26 and $65 \mathrm{kDa}$ proteins from Bacillus thuringiensis subsp. israelensis crystal. FEBS Letters 190, 232-236.
Yamamoto, T., Iizuka, T. \& Aronson, J. N. (1983). Mosquitocidal protein of Bacillus thuringiensis subsp. israelensis: identification and partial isolation of the protein. Current Microbiology 9, 279-284. 